\title{
Comparison of Caries Occurence Between Resin Based and Glass Ionomer Based Pit and Fissure Sealants in Young Permanent Molars After One Year Application
}

\author{
Nila Kasuma ${ }^{1}$, Aida Fitriana ${ }^{1} \&$ Fildzah Nurul Fajrin $^{2}$ \\ ${ }^{1}$ Faculty of Dentistry, Andalas University, Padang, Indonesia \\ ${ }^{2}$ Faculty of Medicine, Andalas University, Padang, Indonesiaa \\ Corresponding Author: Nila Kasuma, Faculty of Dentistry, Andalas University, Jalan Perintis Kemerdekaan Jati \\ Padang, Padang, Indonesia. E-mail: nilakasuma@dent.unand.ac.id
}

Received: July 2, 2018 Accepted: August 18, 2018 Online Published: September 28, 2018

doi:10.5539/gjhs.v10n10p178 URL: https://doi.org/10.5539/gjhs.v10n10p178

\begin{abstract}
The use of anatomic grooves or pits and fissures on the occlusal top of permanent grinders retains food scraps and increases the formation of caries. Inserting and fastening these exposed regions with pit-and fissure sealants has the potential to avert the occurrence of these injuries in teeth. The tools used for such process have the shape of a resin based and a glass ionomer cement (referred to as GIC hereafter). This study aims to compare white spot index (ICDAS) after applying resin based and fissure sealant glass ionomer, and to determine the more efficient types of material over a long period of time method. This study uses experimental pre-test and post-test methods. The research population consists of grade I, II, and III elementary students from the Elementary School No.2, Central Cupak, Padang. Samples were obtained through purposive sampling. The research involves 2 types of sample each of which consists of 30 children who were given resin based sealant application as well as glass Ionomer. ICDAS-II index was used to assess white spot index following one year application. The research data was analyzed with SPSS Statistics through unpaired t-test. The result shows that there is no major distinction between resin based sealant application and glass ionomer cement following one year application $(p=0,23)$. This study concludes that resin based sealants and glass ionomer cement constitute valuable pit and fissure sealant materials. The reaction of these materials must be evaluated over a longer period to determine the mean retention period and to confirm if a new application is needed.
\end{abstract}

Keywords: caries occurence, resin based, glass ionomer based pit, fissure sealants, young permanent molar

\section{Introduction}

A Film of plaque is caused by many circumstances. Such persistent bacterial infection causes the demineralization and the damaging of the hard tissues through the production of acid originating in bacterial fermentation of the food remains amassed on the tooth. Roughly 36\% of the Minangkabau people have dental caries in their permanent teeth (Karpiński \& Szkaradkiewicz, 2013).

Tooth problems such as tooth decay or gingivitis is the most frequent oral cavity infection in Indonesia. According to the Household Health Survey (SKRT), caries prevalence was 90.05\% in 2004. Based on the 2013 Basic Health Research (RISKESDAS), DMF-T Index was 4.6 nationwide, while it was 4,7 in West Sumatera. DM-T rises according to age. The 2007 Padang Basic Health Research points at carries as one of the most frequent tooth problems in West Sumatra (52\% prevalence). Data, as recent as 2013 show a prevalence of 56\%.

Cavity is the final phase of a continuing decrease of the mineralized surface of a tooth. It is a hushed affection relying on the existence of plaques of film as well as the exposure to sugar. These are decisive factors in the development of dental infection (Cury, Maria, Tenuta, \& Enamel remineralization, 2009). Regression period from non-cavitated caries to clinical caries (cavitation) on smooth surfaces is estimated to 18 months \pm 6 months. Peak rates for the incidence of new lesions occur 3 years after the eruption of the tooth. Occlusal pit-and-fissure lesions develop more rapidly than smooth-surface caries. Poor oral hygiene and frequent exposures to sucrose-containing or acidic food can produce noncavitated ("white spot") lesions (first clinical evidence of demineralization) in 3 weeks (Heymann, Swift, Ritter, \& Sturdevant, 2013). 
Caries lesions may affect the teeth in the primary dentition as soon as they erupt into the oral cavity. Some children often have a high degree of destruction in this region. This may reduce chewing efficiency, promote para-functional habits - such as tongue interposition - causing the loss of vertical dimension, and affecting aesthetics, with intense psychological repercussions (Bönecker, Abanto, Tell, \& Oliveira, 2012).

The risk factors of caries are: past caries experience, pit and fissure structures (whereby young patients who have had huge pits and fissures are most likely to have caries). Permanent molars seemed to be prone to decay following four years of appearance (Azarpazhooh \& Main, 2008). Although permanent molars are the most often affected teeth in early age, people tend to neglect them as their think their would be replaced by new ones as they grow older.

The use of anatomic grooves or pits and fissures on the occlusal top of permanent grinders retains food scraps and increases the formation of caries. Inserting and fastening these exposed regions with pit-and fissure sealants has the potential to avert the occurrence of calvity. Some of the elements used for such process are resin based and a glass ionomer cement. Because they have the ability to avert the occurrence of lesions, pit-and fissure sealants are efficient cavity management techniques (Wright et al., 2016). They are some of the most used cavity prevention methods. In fact, $80 \%$ of cavity develop in the pits and fissures of the tooth, which is a fit for the accumulation of plaques and the lack of fluoride (Morales-Chávez \& Nualart-Grollmus, 2014).

\subsection{Objectives}

This study aims to compare the white spot index (ICDAS) after the application of resin based with fissure sealant glass ionomer, and to see the more efficient types of substance over a long period of time method. This study also aims at comparing caries index after resin based and GIC fissure sealants were applied on the surface of young permanent molars for a year.

\section{Methods}

The method used in this research is experimental pre-test and post-test . The research population includes grade I, II, and III students from the Primary School No. 2, Central Cupak, Padang. Purposive method was used to collect data, which consist of two categories: the 1rst category is made up of thirty students given Glass Ionomer Based Pit And Fissure Sealants. 2nd category is also composed of the same number of students who were given the same substances. Before applying the substances, teeth were slowly rinsed with water and pumice stone mixture by using pointed bristle brushes to rid them of debris. Isolation was carried out with cotton rolls for salivation flow control. In the first group, tooth surfaces were dehumidified with an air syringe and corroded with $37 \%$ phosphoric acid followed by a 30 second rinse, and then dried with air for 15 seconds. The etched surface appeared whiter. Sealant materials were applied to polymerization with light curing. Occlusion was checked with articulating paper. In the second group, a mixture of powder and one drop of water was used on each tooth for a minute. Dentine conditioner was used to remove the biofilm and to set the cement properly to the tooth surface for a better sticking. The teeth were washed lightly for 60 seconds, then dried. After the application of pit and fissure, the teeth were flushed for 20-30 seconds. GIC and varnish were applied to pit and fissure. Occlusion was checked with articulating paper. The evaluation was performed at $1^{\text {sr }}, 3^{\text {rd }}, 6^{\text {th }}, 12^{\text {th }}$ over the course of one year. White spot index was measured with ICDAS index. Score of ICDAS (Shivakumar, Prasad, \& Chandu, 2009).

\section{Results}

The research subjects are composed of $63 \%$ male whose average age is $14.18 \pm 7.15$ and $27 \%$ female whose average age is $8.20 \pm 5.91$. Based pit and fissure sealant resin was given to 30 samples while 30 others received glass ionomer.

Table 1. Age of subjects by gender

\begin{tabular}{lllll}
\hline Age & Gender & $\mathbf{n}$ & $\mathbf{\%}$ & Mean \\
\hline \multirow{2}{*}{ 6-9 years old } & Male & 38 & 63 & $7,15 \pm 14,8$ \\
& Female & 22 & 27 & $8,20 \pm 5,91$ \\
\hline
\end{tabular}

ICDAS Index II white spot usage-based fissure sealants was measured with glass ionomer resin following a 12 month usage. 
Table 2. ICDAS Index II white spot resin-based fissure sealants with glass ionomer resin after 1,3,6, and 12 months

\begin{tabular}{llllll}
\hline Variable & $\mathbf{n}$ & \multicolumn{2}{l}{ Mean \pm SD } & & \\
\cline { 3 - 6 } & & 1st & 3rd & 6 th & 12 th \\
\hline Resin based & 30 & $0,00 \pm 0,00$ & $0,00 \pm 0,00$ & $0,00 \pm 0,00$ & $1,07 \pm 0,8$ \\
GIC & 30 & $0,00 \pm 0,00$ & $0,00 \pm 0,00$ & $0,00 \pm 0,00$ & $0,98 \pm 1,01$ \\
\hline
\end{tabular}

Test analysis was performed by using T-test to find out the distinction between based fissure sealants and glass ionomer resin following a 12 month usage.

\section{Discussion}

The present study was carried out at Central Cupak Elementary School No. 02 on students aged from 6 to 9 . Resin-based pit and fissure sealants were given to 30 students while 30 others received glass ionomer cement pit and fissure sealants. This research revealed that no significant distinctions exist between glass ionomer-based fissure sealants and fissure sealant based resin after 1 year usage with value of $p=0,23(p<0,05)$.

This result is in line with the findings of Chavez (2014). No statistical significance was noticed after 6 months. Resin sealant retention was identical with that of the glass ionomer cement after 6 months. Sealant retention was higher on maxillary teeth than on mandibular teeth (Morales-Chávez \& Nualart-Grollmus, 2014). This study is also in line with that of Çubukçu (2009), which found that caries preventive efficacy and survival rate of GIC is inferior to resin based sealant following a 12 month usage (Journal, Stomatology). ${ }^{12}$ The study by Graciano (2015) evaluated sealant retention in two-month interval (2nd, 4th, 6th, 8 th, $10^{\text {th }}$ and 12 th) over the course of one year.

Pit and fissure sealants is a thin layer of plastic placed on the masticatory surfaces of teeth to protect them from tooth decay. Indeed, these faces have pits and furrows in which the bacteria will nest and produce an acid that causes tooth decay. Even with good brushing, it is often difficult to clean these areas well. The dental sealant therefore makes it possible to "seal" these pits and furrows in order to prevent bacteria from entering them (Simonsen \& Neal, 2011).

In this study, both materials showed satisfactory clinical behavior after a six month application. One of the agents that help promote a better clinical behavior of GIC sealant is the presence of resin components that improve the material viscosity and the mechanical and physical properties, thus increasing the retention rate of the material. Moreover, according to Clinpro's manufacturer, material retention should last 6 months, because this is the mean period between dental appointments (Ubramaniam et al., 2015).

GIC could be employed as a temporary preventive means when there are indications for placement of a resin-based sealant. But concerns about moisture control may compromise such placement (Beauchamp et al., 2008). In light of what precedes, we conclude that, under field conditions where moisture control might not be effective, a high-viscosity and less technique-sensitive GIC can be used as a feasible and effective sealant, which is equivalent to its resin counterparts (Oba, Dülgergil, Sönmez, \& Doğan, 2009). Fissure sealants are also predictors of better emotional well-being. Any preventive dental services, such as fissure sealants, may have an effect on the children's emotional well-being domain of oral health quality of life which is so important to support children in school age activity. Having more than four fissure sealants reduced the odds of having emotional stress by $46 \%$ (Alsumait et al., 2015).

There is no difference of ICDAS index between the use of resin based and glass ionomer cement pit and fissure sealant. Each of these elements has different potency during one year.

\section{Conclussion}

There is no remarkable difference of caries index ICDAS-II between the aplication of resin based and glass ionomer cement pit over 1 year usage. Both materials are efficient as pit and fissure sealants. Notwithstanding, the analysis of behavior of this material should be assessed for a longer period to know the mean retention period and verify whether a new application is required. This research is expected to be an input for the government of Indonesia, especially Padang local government, in making health policies. Fissure sealants based on resin and glass ionomer materials can prevent caries in young permanent teeth.

\section{Acknowledgements}

The authors express their gratitude to Kemenristek Dikti which funded this research under the Kemenristek Dikti Regional Elite Research Scheme. We are also thankful to LPPM and FKG Unand for facilitating this research. 


\section{Competing Interests Statement}

The authors declare that there are no competing or potential conflicts of interest.

\section{References}

12. Journal B, Stomatology OF. Retention of Glass Ionomer Cement and Resin-Based Fissure Sealant and Their Effect on Caries Outcome During Chemotherapy: A Pilot Study.

Alsumait, A., ElSalhy, M., Raine, K., Cor, K., Gokiert, R., Al-Mutawa, S., \& Amin, M. (2015). Impact of dental health on children's oral health-related quality of life: a cross-sectional study. Health and quality of life outcomes, 13(1), 98. https://doi.org/10.1186/s12955-015-0283-8

Amin, H. E. (2008). Clinical and antibacterial effectiveness of three different sealant materials. J Dent Hyg., 82(5), 45. http://www.ncbi.nlm.nih.gov/pubmed/19055885.

Azarpazhooh, A., \& Main, P. A. (2008). Pit and fissure sealants in the prevention of dental caries in children and adolescents: a systematic review. $J$ Can Dent Assoc., 74(2), 171-177. Retrieved from www.cda-adc.ca/jcda/vol-74/issue-2/171

Beauchamp, J., Caufield, P. W., Crall, J. J., Donly, K., Feigal, R., Gooch, B., ... \& Simonsen, R. (2008). Evidence-based clinical recommendations for the use of pit-and-fissure sealants: a report of the American Dental Association Council on Scientific Affairs. The Journal of the American Dental Association, 139(3), 257-268. https://doi.org/10.14219/jada.archive.2008.0155

Bönecker, M., Abanto, J., Tell, G., \& Oliveira, L. (2012). Impact of dental caries on preschool children's quality of life: an update. Pediatr Dent. https://doi.org/10.1590/S1806-83242012000700015

Cury, J. A., Maria, L., Tenuta, A., \& Enamel remineralization (2009). Controlling the caries disease or treating early caries lesions? Cariol Braz Oral Res., 23(1), 23-30. https://doi.org/10.1590/S1806-83242009000500005

Graciano, K. P., Moysés, M. R., Ribeiro, J. C., Pazzini, C. A., Melgaço, C. A., \& Ramos-Jorge, J. (2015). One-year clinical evaluation of the retention of resin and glass ionomer sealants on permanent first molars in children. Brazilian Journal of Oral Sciences, 14(3), 190-194. https://doi.org/10.1590/1677-3225v14n3a03

Heymann, H., Swift, E. J., Ritter, A. V., \& Sturdevant, C. M. (2013). Sturdevant's Art and Science of Operative Dentistry. $\quad$ Elsevier/Mosby. Retrieved August 29, 2017, from https://books.google.co.id/books?id=IMbsAwAAQBAJ\&pg=PA56\&lpg=PA56\&dq=The+time+for + progres sion + from + noncavitated + caries + to + clinical + caries $+($ cavitation $)+$ on + smooth + surfaces + is + estimated + to + be $+18+$ months $+ \pm+6+$ months \& source $=$ bl\&ots $=$ m06D4gcYfp\&sig=nrjmeS22NiUqVUiVTrZZHFFUFsY \&hl $=$ en $\& \mathrm{sa}=\mathrm{X} \&$ redir_esc $=\mathrm{y} \# \mathrm{v}=$ onepage $\& \mathrm{q}=$ The time for progression from non-cavitated caries to clinical caries (cavitation) on smooth surfaces is estimated to be 18 months \pm 6 months \& $\mathrm{f}=$-true

Karpiński, T. M., \& Szkaradkiewicz, A. K. (2013). Microbiology of dental caries. J Biol Earth Sci., 3(1), M21-M24.

Mickenautsch, S., \& Yengopal, V. (2016). Caries-preventive effect of high-viscosity glass ionomer and resin-based fissure sealants on permanent teeth: A systematic review of clinical trials. PLoS One, 11(1), 1-19. https://doi.org/10.1371/journal.pone.0146512.

Morales-Chávez, M. C., \& Nualart-Grollmus, Z-C. (2014). Retention of a resin-based sealant and a glass ionomer used as a fissure sealant in children with special needs. $J$ Clin Exp Dent., 6(5), e551-5. https://doi.org/10.4317/jced.51688

Oba, A. A., Dülgergil, T., Sönmez, I. S., \& Doğan, S. (2009). Comparison of Caries Prevention With Glass Ionomer and Composite Resin Fissure Sealants. $J$ Formos Med Assoc. https://doi.org/10.1016/S0929-6646(09)60415-0

Sambhajirao Machale, P., Hegde-Shetiya, S., \& Agarwal, D. (2013). The Incipient Caries. J Contemp Dent., 3(1), 20-24. https://doi.org/10.5005/jp-journals-10031-1029

Shivakumar, K., Prasad, S., \& Chandu, G. (2009). International Caries Detection and Assessment System: A new paradigm in detection of dental caries. $J$ Conserv Dent., 12(1), 10-16. https://doi.org/10.4103/0972-0707.53335

Simonsen, R., \& Neal, R. (2011). A review of the clinical application and performance of pit and fissure sealants. Aust Dent J. https://doi.org/10.1111/j.1834-7819.2010.01295.x 
Ubramaniam, S. P., Onde, K. S., Andanna, M. D. K., et al. (2015). Retention of a resin-based sealant and a glass ionomer used as a fissure sealant: A comparative clinical study. Pesqui Bras Odontopediatria Clin Integr., 18(1), 298-301. https://doi.org/10.1111/j.1365-263X.2007.00855.X

Wright, J. T., Crall, J. J., Fontana, M., Gillette, E. J., Nový, B. B., Dhar, V., ... \& Crespin, M. (2016). Evidence-based clinical practice guideline for the use of pit-and-fissure sealants: a report of the American Dental Association and the American Academy of Pediatric Dentistry. The Journal of the American Dental Association, 147(8), 672-682. https://doi.org/10.1016/j.adaj.2016.06.001

\section{Copyrights}

Copyright for this article is retained by the author(s), with first publication rights granted to the journal.

This is an open-access article distributed under the terms and conditions of the Creative Commons Attribution license (http://creativecommons.org/licenses/by/4.0/). 